\title{
CLINICAL EVALUATION OF THE TREATMENT OF CLAVICLE FRACTURES: INTRAMEDULLARY NAIL $\times$ PLATE
}

\author{
AVALIAÇÃO CLÍNICA DO TRATAMENTO DAS \\ FRATURAS DE CLAVÍCULA: HASTE $\times$ PLACA
}

\author{
Thiago Medeiros Storti ${ }^{1,2}$ (1), Maurício Siqueira Camilo ${ }^{1}$ (i), Rafael Francisco alves Silva ${ }^{2,3}$ (i), \\ Rafael Salomon Silva Faria ${ }^{1}$ (i), Carolina Lima Simionatto ${ }^{1}$ (i), AleXandre Firmino Paniago ${ }^{1,2}$ (i)
}

1. Instituto do Ombro de Brasília, Brasília, DF, Brazil.

2. Hospital Ortopédico e Medicina Especializada, Instituto de Pesquisa e Ensino, Brasília, DF, Brazil.

3. Centro Universitário de Brasília, Brasília, DF, Brazil.

\section{ABSTRACT}

Objective: Studies confirm the benefit of surgical treatment for fixation of displaced midshaft clavicle fractures. Plate fixation and intramedullary nail are the two most used techniques. Our study seeks to compare these two surgical techniques. Methods: This is a retrospective study, conducted by the evaluation of patients treated for displaced midshaft clavicle fracture with intramedullary nail, and plate and screws. Socioeconomic variables were collected, a visual pain scale questionnaire was applied, the shoulder function was measured using CONSTANT and UCLA scores, and radiography was performed to verify the consolidation and evaluation of the final clavicle shortening. Results: Sixty-five patients were evaluated, 36 (55.4\%) of which were subjected to clavicle fixation with plate and screws and 29 (44.6\%) with intramedullary nail. The median shortening was $0.1 \mathrm{~mm}$ for plate and $5.8 \mathrm{~mm}$ for nail $(p=0.001$ ). The UCLA score shows an average of 35 in the plate group and 35 in the intramedullary group. The median CONSTANT scores were 96.5 for plate and 95 for nail, without significance. In all groups, 13 (20\%) complications were registered, 9 fixed with plate and 4 fixed with intramedullary nail. The most common complication was skin erosion with exposure of the synthetic material. Conclusion: The two techniques present satisfactory results for the treatment of displaced midshaft clavicle fractures. Level of Evidence III, Therapeutic Studies Investigating the Results of Treatment.

Keywords: Fractures, Bone. Clavicle. Fracture Fixation. Bone Plates.

\section{RESUMO}

Objetivo: Trabalhos confirmam o benefício do tratamento cirúrgico para fixação de fraturas desviadas do corpo da clavícula. A fixação com placa e haste intramedular são as duas técnicas mais utilizadas. O objetivo deste estudo é comparar as duas técnicas cirúrgicas. Método: Estudo retrospectivo realizado por meio da avaliação de pacientes submetidos à fixação com haste intramedular e com placa e parafusos para o tratamento de fraturas desviadas do corpo da clavícula. Neste caso, foram avaliadas variáveis socioeconômicas, aplicado questionário da escala visual da dor, mensurado a função do ombro pelo escore de CONSTANT e UCLA, e realizada radiografia para verificação da consolidação e avaliação do encurtamento final da clavícula. Resultados: foram avaliados 65 pacientes, destes 36 (55,4\%) foram submetidos à fixação da clavícula com placa e parafusos e 29 (44,6\%) com haste intramedular. A mediana do encurtamento foi $0,1 \mathrm{~mm}$ para placa e $5,8 \mathrm{~mm}$ para haste $(p=0,001)$. O escore de UCLA apresentou mediana de 35 no grupo placa e 35 no grupo haste. O escore de Constant mostrou mediana de 96,5 no grupo placa e 95 no grupo haste, sem diferença significativa entre os grupos. Ao todo, foram registradas 13 (20\%) complicações, 9 do grupo fixado com placa e 4 do grupo fixado com haste. A complicação mais comum foi a erosão da pele com exposição do material de sintese. Conclusão: as duas técnicas apresentam resultados satisfatórios para o tratamento das fraturas do corpo da clavícula. Nível de Evidência III, Estudos terapêuticos - Investigação dos resultados do tratamento.

Descritores: Fraturas ósseas. Clavícula. Fracture Fixation. Placas ósseas.

Citation: Storti TM, Camilo MS, Silva RFA, Faria RSSF, Simionatto CL, Paniago AF. Clinical evaluation of the treatment of clavicle fractures: intramedullary nail $\times$ plate. Acta Ortop Bras. [online]. 2021;29(1):34-8. Available from URL: http://www.scielo.br/aob.

\section{INTRODUCTION}

Clavicle fractures represent $2-5 \%$ of all fractures in adults. ${ }^{1-7}$ They are more common in men in the second decade of life. ${ }^{3,5}$ The main mechanisms of fracture are automobile accidents and sports traumas. $3,7,8$ They can be divided according to location, with the clavicle midshaft being the most affected, accounting for $80 \%$ of the cases. ${ }^{2-4,6-10}$ Furthermore, fractures of the clavicle midshaft tend to be diverted. ${ }^{4.8 .9}$

All authors declare no potential conflict of interest related to this article.

The study was conducted at Hospital Ortopédico e Medicina Especializada, Instituto de Pesquisa e Ensino.

Correspondence: Rafael Francisco. QNE 20 CASA 19, Taguatinga Norte, Brasília, DF, Brazil, 72125200. rafafalves97@gmail.com 
Exposed, diverted high energy fractures, with severe comminution and shortening greater than $2 \mathrm{~cm}$ are the main indicators of surgical fixation. ${ }^{11}$ In these cases, surgical treatment has advantages in consolidation rates, lower shortening rates, lower persistence of pain, earlier return to daily activities, greater mobility and shoulder strength, and better aesthetic satisfaction.1-4,8,9,12-14 Different techniques have been described for clavicle fixation, among which the two most used are the plate and the intramedullary nail., ${ }^{1,7,8,14,15}$

The two fixation techniques have advantages, and plate fixation is considered the gold standard due to its better stabilization when compared with the nail. ${ }^{1,2,7}$ The intramedullary nail appeared as an alternative because it is less invasive, since it preserves the adjacent soft tissue, periosteum and vascular integrity at the fracture site. Thus, it presents lower infection rates, better aesthetic results and lower cost. ${ }^{1,2,5,8}$

Few studies have compared the best surgical technique for fixation of clavicle fractures. The objective of our study is to compare the clinical and radiographic results of patients subjected to surgical fixation treatment with intramedullary plate or nail of fractures diverted from the body of the clavicle, since they are the two most used techniques.

\section{MATERIALS AND METHODS}

A retrospective cohort study was conducted, with multivariate analyses of the data obtained by the review of medical records, postoperative clinical reassessment and comparative radiographs of patients subjected to surgical treatment of the clavicle fracture. From January 2011 to August 2017, patients operated for surgical treatment with fractures diverted from the clavicle midshaft fixed with plate and screws or flexible titanium nail were evaluated. The study was conducted in two reference centers, with the same team of surgeons, composed of two shoulder specialists.

The volunteers were selected based on the following inclusion and exclusion criteria:

\section{Inclusion criteria}

Individuals aged 18 years or over; fractures of the clavicle midshaft with fixation with plate and screws or intramedullary nail; and at least 6 months postoperatively.

\section{Exclusion criteria}

Fracture of the lateral third; fracture associated with brachial plexus injury; associated lesions in the operated shoulder; patients that were not located or that refused to participate in the study. In total, 95 patients were operated, 65 contributed to the study, and the main exclusion factor was the loss of patients in the follow-up. The study design was submitted and approved by the local ethics committee on CAAE 70804317.7.0000.0023.

\section{Evaluation criteria}

During the reassessment, sociodemographic, anthropometric and clinical variables were collected. Pain measurement was performed using the visual analog scale. Shoulder function and postoperative patient quality of life were evaluated by the Constant-Murley (CONSTANT) and University of California at Los Angeles (UCLA) scales. On the day of the evaluation, the volunteers were subjected to a new radiography in anteroposterior incidence and ZANCA, comparatively, including the two clavicles. Thus, the consolidation and length of the clavicle, which is its extension from the acromial extremity to the sternal articular face, were evaluated, being measured by two evaluators, using the mean of the values found as the final result (Figures 1 and 2).

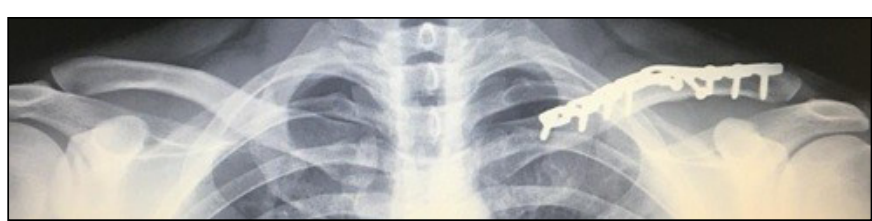

Figure 1. Radiography with anteroposterior incidence and ZANCA, including comparatively the two clavicles after fixation with plate.

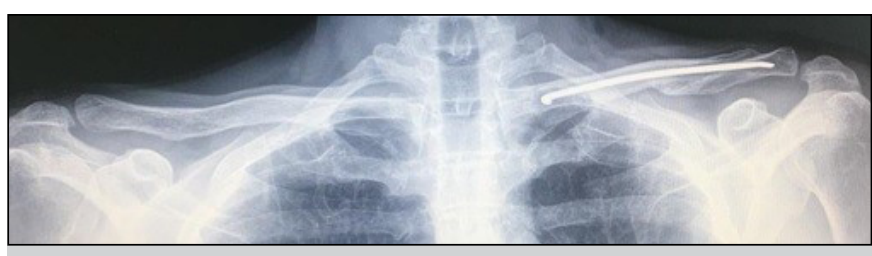

Figure 2. Radiography with anteroposterior incidence and ZANCA, including comparatively the two clavicles after fixation with plate.

\section{Surgical description}

In both groups, locorregional anesthesia with brachial plexus block and general anesthesia was used, in addition to antibiotic prophylaxis with cefazolin.

In the group of patients subjected to fixation of fractures with plate and screws, Synthes ${ }^{\circledR}$ precast blocked LCP plates of $3.5 \mathrm{~mm}$ stainless steel for clavicle were used. The access route was through upper, horizontal incision, and opening of the muscular fascia. After reduction under direct visualization of the focus, the plate was placed in the upper part of the clavicle and fixed with at least 3 screws in each main fragment. In most cases, the principle of relative stability was used due to the fragmentation of the fracture focus. In some cases, with oblique features and no fragmentation, interfragmented screws with compression of the fracture focus were used.

In the nail group, a medial entry point into the clavicle was used through a $1 \mathrm{~cm}$ anterior horizontal incision, laterally to the sternoclavicular joint. The bone entry point was at the lower edge of the medial clavicle, at a point approximately $1 \mathrm{~cm}$ lateral to the sternoclavicular joint, performed with a $2.5 \mathrm{~mm}$ awl. Each fracture was fixed with only one flexible nail, with a diameter ranging from 2.0 to $3.0 \mathrm{~mm}$, chosen according to the size of the clavicular medullary canal. A reduction was performed either manually or by means of pointed tweezers for percutaneous manipulation of the fragments. When the closed reduction was not achieved, a vertical incision of $2.0 \mathrm{~cm}$ was made on the focus and direct fracture reduction. After the nail overtook the fracture focus, it was advanced to the lateral clavicle, piercing the rheterolateral cortical. Finally, the nail was cut close to the medial entry point and the fascia was sutured over it. The intramedullary nail was removed at the end of treatment, but the plate was removed only in cases in which they caused discomfort.

\section{Rehabilitation}

The rehabilitation protocol for both groups consisted of immobilization with a sling for four weeks, starting the gain of the range of movements after two weeks, with self-passive exercises. From the fifth week on, the patients were referred to physical therapy to initiate active movement. Muscle strengthening and return to complete activities were allowed after complete fracture consolidation.

\section{Follow-up period}

Initially, the services adopted the exclusive use of fixation with plate and screws in clavicle fractures until January 2015, and the method was completely replaced by fixation with intramedullary nail, regardless of the type of fracture. Thus, the average follow-up period of patients treated with plate was longer than patients treated with intramedullary nail ( 3 years and 4 months and 1 year and 7 months, respectively). 


\section{Statistical description}

The comparison of numerical variables between two groups of synthesis material was performed by the Mann-Whitney test (nonparametric), and for categorical data, the chi-square $\left(x^{2}\right)$ or Fisher's exact tests were applied. Spearman's correlation coefficient (r) was used for the association between numerical variables.

Significance level was set at $5 \%$. Statistical analysis was processed by statistical software SAS ${ }^{\circledR}$ System, version 6.11 (SAS Institute, Inc., Cary, North Carolina).

\section{RESULTS}

During the period, 95 patients underwent surgery. Of these, 65 were included.

\section{Epidemiology}

Of the 65 volunteers, 36 (55.4\%) were subjected to fixation of the clavicle with plate and 29 (44.6\%) with intramedullary nail (Table 1).

\begin{tabular}{|c|c|c|c|c|}
\hline Variable & \multicolumn{2}{|c|}{ Plate (36) } & \multicolumn{2}{|c|}{ Nail (29) } \\
\hline Age (years) & & & & \\
\hline Mean (range) & \multicolumn{2}{|c|}{$37.5(18-69)$} & \multicolumn{2}{|c|}{$37.8(18-75)$} \\
\hline Gender & & & & \\
\hline Male & 33 & $91.7(\%)$ & 23 & $79.3(\%)$ \\
\hline Female & 3 & $8.3(\%)$ & 6 & $20.7(\%)$ \\
\hline \multicolumn{5}{|l|}{ Physical Activity } \\
\hline Sedentary & 9 & $25.0(\%)$ & 6 & $20.7(\%)$ \\
\hline Moderate & 15 & $41.7(\%)$ & 15 & $51.7(\%)$ \\
\hline active & 12 & $33.3(\%)$ & 8 & $27.6(\%)$ \\
\hline \multicolumn{5}{|l|}{ BMI (kg/m ) } \\
\hline median & \multicolumn{2}{|c|}{26.9} & \multicolumn{2}{|c|}{24.4} \\
\hline
\end{tabular}

Men accounted for $86.2 \%(n=56)$ of the patients treated. The main mechanisms of trauma were automobile accidents, followed by sports trauma. The mean age in the fracture event was $37.5 \pm 12$ years (range 17-75).

Clavicle shortening and shoulder function:

Clavicle shortening is given by the difference between the length of the unfractured side and the fractured side. Its median was $0.9 \mathrm{~mm}$ (range $-3.5-14$ ) in the plate group and $5.8 \mathrm{~mm}$ (range $-0.8-14.4$ ) in the nail group ( $p=0.001$ ) (Figures 1 and 2$)$. The median CONSTANT scores were 96.5 (range 80 - 100) in the plate group and 95 (range 79 - 100) in the nail group, whereas the UCLA score had a median of 35 (range 21 - 35) for plate and 35 (interval 29 - 35) for the nail. Based on Spearman's score, there was no association between clavicle shortening and shoulder function by CONSTANT score $(r=0.009)$ and UCLA $(r=0.045)$ (Table 2$)$.

Table 2. Shortening rate and shoulder function - Plate $\times$ Nail.

\begin{tabular}{c|c|c|c|c}
\hline & Plate $(\mathbf{n}=\mathbf{3 6})$ & Nail $(\mathbf{2 9})$ & $\mathbf{p}$ valor & $\mathbf{r}$ \\
\hline Median Shortening $(\mathrm{mm})$ & $0.9(-3.5-14)$ & $5.8(-0.8-14.4)$ & 0.001 & \\
\hline Median CONSTANT Score & $96.5(80-100)$ & $95(79-100)$ & 0.66 & 0.009 \\
\hline Median UCLA SCORE & $35(21-35)$ & $35(29-35)$ & 0.23 & 0.045 \\
\hline
\end{tabular}

Shoulder shortening and function stratified by the type of fracture By Robinson's rating, 36 (55.3\%) patients had type 2B1 and $28(43.0 \%)$ fracture type 2B2. Of the fractures 2B1, 17 (48.5\%) were fixed with plate and 18 (51.4\%) with nail, whereas among fractures 2B2, 18 (64.2\%) were fixed with plate and 10 (35.7\%) with nail.
When analyzing the fixation method stratified by the type of fracture, we observed that the median shortening of fractures in group 2B1 was $1.3 \mathrm{~mm}$ (interval -1.1 - 10) for plate and $5.5 \mathrm{~mm}$ (interval 0.9 - 13.9) for nail. Thus, $2 \mathrm{~B} 1$ fractures present significantly lower shortening when fixed with plate $(p=0.018)$. In the 2B2 fracture group, a median of $0.75 \mathrm{~mm}$ (range -3.5-14) for plate and $9.75 \mathrm{~mm}$ (range -0.8-14.4) for the nail was observed, with shortening in the plate group significantly lower $(p=0.029)$.

The 2B1 fractures fixed with plate presented a mean CONSTANT score of 95.2 (interval $82-100$ ) and an average UCLA score of 35 (range 35-35). When fixed with nail, the mean CONSTANT score was 95.3 (range 79 - 100) and the mean UCLA score was 34.6 (range 29 - 35). The two fixation methods for 2B1 fractures do not present significant difference compared to the score of CONSTANT $(p=0.7)$ and UCLA $(p=0.17)$.

In the 2B2 fractures fixed with plate, similar values were observed in the scores, and the mean CONSTANT score was 93.6 (interval 79 - 100) and the mean UCLA score, 34.3 (interval 21 - 35). The same was observed in fixation with nail, with mean CONSTANT score of 93.9 (range 86 - 100) and average UCLA of 34.8 (range 21 - 35). The two techniques showed no significant difference in UCLA ( $p=0.68)$ and CONSTANT ( $p=0.94$ ) (Table 3 ) scores.

Table 3. Shortening and function of the shoulder stratified by the type of fracture.

\begin{tabular}{c|c|c|c|c|c|c}
\hline \multicolumn{4}{|c|}{ 2B1 $(\mathbf{n = 3 6})$} & \multicolumn{3}{|c}{ 2B2 (n= 29) } \\
\hline & $\begin{array}{c}\text { Plate } \\
(\mathbf{n}=17)\end{array}$ & $\begin{array}{c}\text { Nail } \\
(\mathbf{n}=19)\end{array}$ & $\begin{array}{c}\mathbf{p} \\
\text { valor }\end{array}$ & $\begin{array}{c}\text { Placa } \\
(\mathbf{n}=19)\end{array}$ & $\begin{array}{c}\text { Nail } \\
(\mathbf{n}=10)\end{array}$ & $\begin{array}{c}\mathbf{p} \\
\text { valor }\end{array}$ \\
\hline $\begin{array}{c}\text { Median } \\
\text { Shortening } \\
(\mathrm{mm})\end{array}$ & $\begin{array}{c}1.30 \\
(-1.1-10)\end{array}$ & $\begin{array}{c}5.50 \\
(0.9-13.9)\end{array}$ & 0.018 & $\begin{array}{c}0.75 \\
(-3.5-14)\end{array}$ & $\begin{array}{c}9.75 \\
(-0.8-14.4)\end{array}$ & 0.029 \\
\hline $\begin{array}{c}\text { Median } \\
\text { CONSTANT } \\
\text { Score }\end{array}$ & 98 & 100 & & 95 & 94 & \\
\hline $\begin{array}{c}\text { Median UCLA } \\
\text { SCORE }\end{array}$ & $\begin{array}{c}35 \\
(35-35)\end{array}$ & $\begin{array}{c}35 \\
(79-100)\end{array}$ & 0.70 & $(80-100)$ & $(86-100)$ & 0.94 \\
\hline
\end{tabular}

Pain

Patients operated with nails have a tendency to have more intense/ moderate pain in the immediate postoperative period compared to patients operated with plate and screws $(p=0.062)$. Most patients in both groups evolved without pain; however, when pain remains present, the tendency is to be in patients fixed with plate and screws $(p=0.93)$ (Table 4)

Table 4. Pain distribution.

\begin{tabular}{|c|c|c|c|c|c|}
\hline & \multicolumn{2}{|c|}{ Plate $(n=36) \%$} & \multicolumn{2}{|c|}{ Nail $(n=29) \%$} & \multirow[t]{2}{*}{ P valor } \\
\hline Immediate postoperative pain & & & & & \\
\hline Absent & 6 & 16.7 & 6 & 20.7 & \\
\hline mild & 16 & 44.4 & 9 & 31.0 & \\
\hline Moderate & 7 & 19.4 & 13 & 44.8 & \multirow{2}{*}{0.062} \\
\hline Intense & 7 & 19.4 & 1 & 3.4 & \\
\hline \multicolumn{6}{|l|}{ Current pain } \\
\hline Absent & 30 & 83.3 & 28 & 96.6 & \multirow{2}{*}{0.093} \\
\hline mild & 6 & 16.7 & 1 & 3.4 & \\
\hline
\end{tabular}

\section{Patient satisfaction}

Patients treated with nail have a tendency of greater aesthetic satisfaction with the scar when compared with the plate group $(p=0.93)$ (Table 5). 
Table 5. Aesthetic satisfaction of the surgical scar

\begin{tabular}{c|c|c|c}
\hline Physical/aesthetic discomfort & Plate $(\mathbf{n = 3 6}) \%$ & Nail $(\mathbf{n = 2 9}) \%$ & \multirow{2}{*}{ p valor } \\
\hline Yes & 616.7 & 13.4 & \multirow{2}{*}{0.093} \\
\hline No & 3083.3 & 2896.6 & \\
\hline
\end{tabular}

\section{Complications}

In total, 13 (20\%) complications of surgical treatment were registered. In the group fixed with plate, nine (25\%) presented complications: seven presented major complications (plate loosening, plate breakage and skin erosion with plate exposure) and two minor complications (delayed consolidation and discomfort at the surgical site). In the group fixed with nail, there were four (13.7\%) complications. Of these, three complications were major (skin erosion with nail exposure, deep infection and pseudoarthrosis) and one minor (prominent synthesis). However, there was no significant difference between the groups $(p=0.45)$ (Table 6$)$.

Table 6. Complications.

\begin{tabular}{c|c|c}
\hline & Plate (n) \% & Nail (n) (\%) \\
\hline Major complications & $\mathbf{7 1 9 . 4 4}$ & $\mathbf{3 1 0 . 3 4}$ \\
\hline Prosthesis loosening & 25.55 & \\
\hline Break of the synthesis material & 12.77 & \\
\hline Skin erosion with synthesis material exposure & 411.1 & 13.44 \\
\hline Deep Infection & & 13.44 \\
\hline Pseudoarthrosis & & 13.44 \\
\hline Minor complications & $\mathbf{2 5 . 5 5}$ & $\mathbf{1 3 . 4 4}$ \\
\hline Consolidation delay & 12.77 & \\
\hline Surgical site infection & 12.77 & \\
\hline Outstanding synthesis & & 13.44
\end{tabular}

\section{Follow-up period}

In our service, plate treatment was replaced by intramedullary nail, resulting in a longer average follow-up period for patients treated with plate compared to patients treated with intramedullary nail ( 3 years and 4 months and 1 year and 7 months, respectvely).

\section{DISCUSSION}

Our study compared the result of surgical treatment by fixation with plate and screws and intramedullary nail of diverted fractures of the clavicle midshaft. For such purpose, 65 volunteers were reevaluated clinically and radiographically after a minimum period of 6 months of follow-up, which were divided according to the fixation used - plate or nail.

The epidemiological profile of our study was similar to that found in other studies. $3,5,7,8$ Men were the most affected, accounting for $86.2 \%(n=56)$, and the most vulnerable age group was 29 to 49 years. The main mechanisms of trauma were automobile accidents, followed by sports trauma.

The main complications of plate treatment are loosening or failure of the synthesis material, paresthesia at the incision site, injury of neurovascular structures, pseudarthrosis, discomfort at the surgical site due to the presence of plate and refracture after plate removal. $3,7,16,17$ On the other hand, the main disadvantages of nail use are nail migration, skin irritation and the frequent need for removal. ${ }^{17}$ In our study, the complication rate was $20 \%$, being similar to other studies. ${ }^{18-21}$ In a meta-analysis conducted by Wang et al., ${ }^{17}$ the frequency of postoperative complications was similar in both forms of fixation. Based on our results, the group fixed with plate presented the highest number of complications ( $n=9$ ), but without significant difference when compared with the group fixed with nail $(n=4)$. Skin erosion with the exposure of the synthesis material was the main complication $(n=5)$, being observed in 4 cases in the group fixed with plate and in 1 case in the group treated with nail.

In a meta-analysis performed by Wijicks et al., ${ }^{22}$ the infection in the treatment using plate presented a rate lower than $10 \%$ in 9 articles analyzed, and in 2 articles rates higher than this value were found. In our study, we did not observe any case of deep or superficial infection in the group fixed with plate. However, we had one case (3.44\%) of skin erosion with exposure of the nail that evolved with deep infection. The approach adopted was the removal of the nail, the debridement of the lesion and antibiotic therapy, evolving with complete consolidation and resolution of the infectious condition. Govindasamy et al..$^{15}$ had a rate of $5.6 \%$ of superficial skin infection in patients treated with nail, and oral antibiotic treatment was recommended in these cases.

Problems at the site of implantation of the plate, generating necrosis of the skin, may have outcomes that require debridement, removal and revision of fixation. Its rate in the literature ranges from 10 to $53 \%{ }^{22}$ In our study, the rate of skin erosion with plate exposure was $11.1 \%(n=4)$ in the group fixed with plate and screws. All patients were treated with plate removal and necrotic tissue debridement. In a single case, 3 weeks after surgery, the fracture was not yet consolidated, and the plate was replaced by the nail, with subsequent consolidation.

Zlowodzki et al. ${ }^{23}$ conducted a systematic review with 2,144 patients treated surgically and conservatively, and the pseudarthrosis rate of $5.9 \%$ in conservative treatment, $2.5 \%$ in plate surgical treatment and $1.6 \%$ with nail were found. In radiographic analysis, we observed only one case of pseudarthrosis (1.53\%), in a 75 -year-old patient, victim of fall to the ground with consequent fracture of the right clavicle and left proximal humerus. She was subjected to surgical treatment of the two fractures in the same procedure, performing fixation with intramedullary nail of the clavicular fracture (Figure 3).

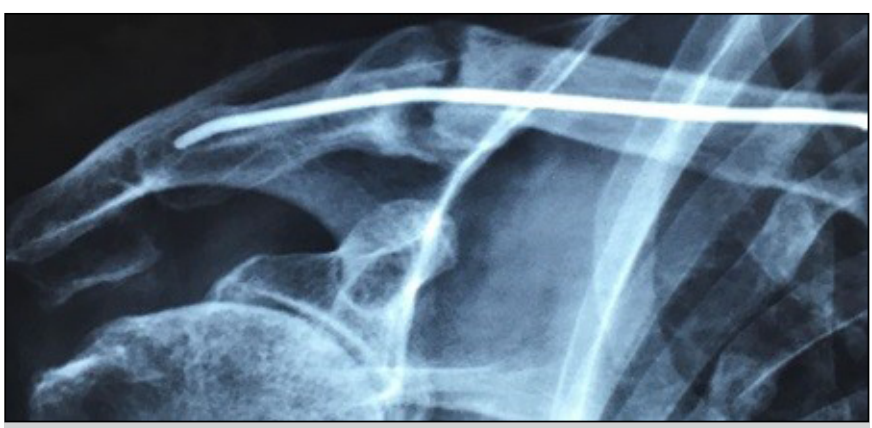

Figure 3. X-ray confirming pseudoarthrosis

Although the relationship of clavicular shortening with shoulder dysfunction is controversial in the literature, Matsumura et al., ${ }^{24}$ demonstrated that clavicle shortening leads to decreased lateral rotation of the shoulder and posterior inclination of the scapula during elevation, and these anatomical changes may have symptomatic repercussions for the patient. On the other hand, Rasmussen et al., ${ }^{25}$ in a retrospective study with 136 patients with conservative treatment, concluded that shortening of $20 \mathrm{~mm}$ or more is not associated with shoulder dysfunction.

In our study, when comparing the shortening of patients fixed with plate and nail, a median shortening of $0.9 \mathrm{~mm}$ (interval -3.5 - 14) was observed in the plate group and 5.8 (interval -0.8 - 14.4) in the nail group ( $p=0.001$ ). If we stratified by the type of fracture, the greatest shortening of the 2B1 fractures was $10 \mathrm{~mm}$ for plate and $13.9 \mathrm{~mm}$ for nail, and of 2B2 fractures, the largest shortening was $14 \mathrm{~mm}$ for plate 
and $14.4 \mathrm{~mm}$ for nail. When relating shortening with shoulder function, using CONSTANT and UCLA scores, we conclude that there was no reduction in shoulder function. Thus, the plate and intramedullary nail present satisfactory results regardless of the type of fracture. Andrade-Silva et al. ${ }^{26}$ conducted a prospective study, in which they compared 26 patients subjected to the treatment of clavicle fractures with intramedullary nail and 33 subjected to plate and screw fixation, including both simple fractures and complex fractures in both groups. There were no significant differences between the groups at the time of consolidation, functional scores or complication rate.

Plate fixation presents greater damage to the soft tissue adjacent to the fracture due to its invasive nature. ${ }^{1,2}$ However, in our study, when pain was present, the group of patients treated with plate presented a tendency $(p=0.062)$ to lower moderate/severe pain in the immediate postoperative period compared to patients treated with nail. Eden et al. ${ }^{27}$ performed the pain evaluation of 102 patients and found that in the immediate postoperative period, the treatment with plate and nail presented similar pain values. However, the patients operated with nail evolved with less pain compared to patients operated with plate. In our series, we observed that patients from both groups tended to evolve without pain. On the other hand, cases that evolved with pain were more likely to have undergone fixation with plate $(p=0.93)$.
In a meta-analysis performed by Zhang et al., ${ }^{28}$ the hypertrophic aspect of the scar of patients treated with plate and nail was evaluated. The group fixed with nail presented hypertrophic scar rate of $2.3 \%$, whereas the rate in the group fixed with plate was $15.7 \%$. Regarding the aesthetic satisfaction of our patients, the group treated with a nail showed greater satisfaction with the aesthetic aspect of the scar, since the treatment with plate results in larger scars. Our study presents as main limitations the fact that it is a retrospective research and for this reason, the groups present different follow-up time, which makes the comparative evaluation of the groups difficult. Another limitation is the limited number of patients evaluated. The realization of new prospective studies with long-term follow-up will be important for more definitive conclusions on the best form of surgical treatment of these fractures so common and important in orthopedic practice.

\section{CONCLUSION}

Treatment with plate and screws or intramedullary nail for fractures diverted from the clavicle midshaft does not present important differences in consolidation indices, functional scores or patient satisfaction index. Although the treatment with nail presented greater shortening of the clavicle, there was no association with the reduction of shoulder function. Thus, according to functional scores, both techniques present satisfactory results for the treatment of this type of fracture.

AUTHORS' CONTRIBUTIONS: Each author contributed individually and significantly to the development of this article. TMS: study conception and design, data collection, analysis and interpretation, writing and critical review; MSC: conception, data collection, writing; RFAS: study conception and design, data collection, analysis and interpretation, writing and critical review; RSSF: data interpretation, writing; CLS: writing; AFP: study design and writing.

\section{REFERENCES}

1. Houwert RM, Wijdicks FJ, Bisschop CS, Verleisdonk EJ, Kruyt M. Plate fixation versus intramedullary fixation for displaced mid-shaft clavicle fractures: a systematic review. Int Orthop. 2012;36(3):579-85

2. Golish SR, Oliviero JA, Francke EI, Miller MD. A biomechanical study of plate versus intramedullary devices for midshaft clavicle fixation. J Orthop Surg Res. 2008;3:28.

3. Houwert RM, Smeeing DPJ, Ali UA, Hietbrink F, Kruyt MC, van der Meijden OA. Plate fixation or intramedullary fixation for midshaft clavicle fractures: a systematic review and meta-analysis of randomized controlled trials and observational studies. J Shoulder Elbow Surg. 2016;25:1195-203.

4. Martetschläger F, Gaskill TR, Millett PJ. Management of clavicle nonunion and malunion. J Shoulder Elbow Surg. 2013;22(6):862-8.

5. Hanselman AE, Murphy TR, Bal GK, McDonough EB. Operative Cost Comparison: Plating Versus Intramedullary Fixation for Clavicle Fractures. Orthopedics. 2016;39(5):e877-82.

6. Wang J, Meng XH, Guo ZM, Wu YH, Zhao JG. Interventions for Treating Displaced Midshaft Clavicular Fractures. Medicine. 2015;94(11):e595.

7. Ni M, Niu W, Wong DWC, Zeng W, Mei J, Zhang M. Finite element analysis of locking plate and two types of intramedullary nails for treating mid-shaft clavicle fractures. Injury. 2016;47(8):1618-23.

8. Calbiyik M, Zehir S, Ipek D. Minimally invasive implantation of a novel flexible intramedullary nail in patients with displaced midshaft clavicle fractures. Eur J Trauma Emerg Surg. 2016;42(6):711-7.

9. van der Meijden OA, Gaskill TR, Millett PJ. Treatment of clavicle fractures: current concepts review. J Shoulder Elbow Surg. 2012;21(3):423-9

10. Huang TL, Chen WC, Lin KJ, Tsai CL, Lin KP, Wei HW. Conceptual finite element study for comparison among superior, anterior, and spiral clavicle plate fixations for midshaft clavicle fracture. Med Eng Phys. 2016;38(10):1070-5.

11. Bradbury N, Hutchinson J, Hahn D, Colton CL. Clavicular nonunion. $31 / 32$ healed after plate fixation and bone grafting. Acta Orthop Scand. 1996;67(4):367-70.

12. Ai J, Kan SL, Li HL, Xu H, Liu Y, Ning GZ, et al. Anterior inferior plating versus superior plating for clavicle fracture: a meta-analysis. BMC Musculoskelet Disord. 2017;18:159.

13. Figueiredo EA, Neves EJ, Yoshizawa Júnior H, Dall'Ara Neto A, Nascimento LFC, Faria GHM, et al. Estudo prospectivo randomizado comparativo entre os tratamentos cirúrgico utilizando placa anterior e o não cirúrgico das fraturas do terço médio da clavícula. Rev Bras Ortop. 2008;43(10):419-25.

14. Souza NASM, Belangero PS, Figueiredo EA, Pochini AC, Andreoli CV, Ejnisman B. Fratura do terço médio da clavícula em atletas -Devemos operar? Rev Bras Ortop. 2018;53(2):171-5.

15. Govindasamy R, Kasirajan S, Meleppurame JJ, Thonikadavath F. Estudo retrospectivo de haste intramedular estável elástica de titânio em fraturas deslocadas do terço médio da clavícula. Rev Bras Ortop. 2017;52(3):270-7.
16. Silva FBA, Kojima KE, Silva JS, Mattar Junior R. Comparação entre o uso de placas e o de hastes flexíveis para a osteossíntese de fraturas do terço médio da clavícula: resultados preliminares. Rev Bras Ortop. 2011;46(1):34-9.

17. Wang XH, Cheng L, Guo WJ, Li AB, Cheng GJ, Lei T, et al. Plate Versus Intramedullary Fixation Care of Displaced Midshaft Clavicular Fractures. Medicine. 2015;94(41):e1792.

18. Sawalha S, Guisasola I. Complications associated with plate fixation of acute midshaft clavicle fractures versus non-unions. Eur J Orthop Surg Traumatol. 2018;28(6):1059-64.

19. Persico F, Lorenz E, Seligson D. Complications of operative treatment of clavicle fractures in a Level I Trauma Center. Eur J Orthop Surg Traumatol. 2014;24(6):839-44

20. Asadollahi S, Hau RC, Page RS, Richardson M, Edwards ER. Complications associated with operative fixation of acute midshaft clavicle fractures. Injury. 2016;47(6):1248-52.

21. Fridberg M, Ban I, Issa Z, Krasheninnikoff M, Troelsen A. Locking plate osteosynthesis of clavicle fractures: complication and reoperation rates in one hundred and five consecutive cases. Int Orthop. 2013;37(4):689-92.

22. Wijdicks FJG, Van der Meijden OAJ, Millett PJ, Verleisdonk EJMM, Houwert RM. Systematic review of the complications of plate fixation of clavicle fractures. Arch Orthop Trauma Surg. 2012;132(5):617-25.

23. Zlowodzki M, Zelle BA, Cole PA, Jeray K, McKee MD. Treatment of Acute Midshaft Clavicle Fractures: Systematic Review of 2144 Fractures. J Orthop Trauma. 2005;19(7):504-7.

24. Matsumura N, Ikegami $H$, Nakamichi N, Nakamura T, Nagura T, Imanishi N, et al. Effect of Shortening Deformity of the Clavicle on Scapular Kinematics. Am J Sports Med. 2010;38(5):1000-6.

25. Rasmussen JV, Jensen SL, Petersen JB, Falstie-Jensen T, Lausten G, Olsen BS. A retrospective study of the association between shortening of the clavicle after fracture and the clinical outcome in 136 patients. Injury. 2011;42(4):414-7.

26. Andrade-Silva FB, Kojima KE, Joeris A, Silva JS, Mattar R Jr. Single, superiorly placed reconstruction plate compared with flexible intramedullary nailing for midshaft clavicular fractures: a prospective, randomized controlled trial. J Bone Joint Surg Am. 2015;97(8):620-6.

27. Eden L, Ziegler D, Gilbert F, Fehske K, Fenwick A, Meffert RH. Significant pain reduction and improved functional outcome after surgery for displaced midshaft clavicular fractures. J Orthop Surg Res. 2015;10:190.

28. Zhang B, Zhu Y, Zhang F, Chen W, Tian Y, Zhang Y. Meta-analysis of plate fixation versus intramedullary fixation for the treatment of mid-shaft clavicle fractures. Scand J Trauma Resusc Emerg Med. 2015;23:27. 